\title{
Stem cells and tissue engineering in plastic surgery: an update
}

\author{
Gregory R. D. Evans, Alan D. Widgerow \\ Department of Plastic Surgery, University of California, Irvine, Orange, CA 92868, USA.
}

Correspondence to: Prof. Gregory R. D. Evans, Department of Plastic Surgery, University of California, Irvine, 200 S Manchester Suite 650, Orange, CA 92868, USA. E-mail: gevans@hs.uci.edu

How to cite this article: Evans GRD, Widgerow AD. Stem cells and tissue engineering in plastic surgery: an update. Plast Aesthet Res 2020;7:28. http://dx.doi.org/10.20517/2347-9264.2019.53

Received: 7 Nov 2019 First Decision: 18 Feb 2020 Revised: 19 Feb 2020 Accepted: 6 Mar 2020 Published: 30 May 2020

Science Editors: Yi-Lin Cao, Raúl González-García Copy Editor: Jing-Wen Zhang Production Editor: Tian Zhang

\begin{abstract}
Stem cells and tissue engineering have made great strides in plastic surgery. This review of the literature evaluates some current background information and recent advances in our laboratory to bring these areas more into the clinical setting.
\end{abstract}

Keywords: Stem cells, plastic surgery, fat

\section{INTRODUCTION}

Plastic surgeons are innovative. The specialty has been founded on cutting technology, new ways to look at procedures and adaptive behavior. Plastic surgeons have embraced the field of regenerative medicine and have attempted to understand stem cell technology and fat grafting and how this might relate and apply to the clinical setting ${ }^{[1-5]}$. Unfortunately despite much progress, there remains significant unanswered questions on clinical applicability and our ability to regulate and adjust these cells for clinical use.

Embryonic stem cells were first isolated and described by Dr. James Thomson at the University of Wisconsin in $1998^{[5-13]}$. The pluripotent nature of these cells generated a great deal of excitement but with this excitement came concerns on potential embryonic sacrifice along with the potential experimental concern with the use of these cells. Consequently, the use of embryonic stems cells has been isolated to a few discrete clinical trials ${ }^{[14-20]}$.

Induced pluripotent cells (iPS cells) are genetically modified cells that take on the characteristic of embryonic stem cells. The initial excitement over the use of these cells revolved around the opportunity

cc) (7) (C) The Author(s) 2020. Open Access This article is licensed under a Creative Commons Attribution 4.0 International License (https://creativecommons.org/licenses/by/4.0/), which permits unrestricted use, sharing, adaptation, distribution and reproduction in any medium or format, for any purpose, even commercially, as long as you give appropriate credit to the original author(s) and the source, provide a link to the Creative Commons license, and indicate if changes were made.

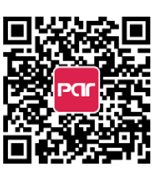


for researchers to utilize a cell with similar pluripotency but with the lack of embryonic moral concerns relating to embryonic stem cells ${ }^{[21-30]}$. However, concerns on genetic modification along with tumorigenic potential has led to caution for clinical indications ${ }^{[31-56]}$.

Adult stem cells, although not as robust as embryonic stem cells, carry significant potential in regenerative medicine and, with their abundance in fat, carry great significance to plastic surgeons ${ }^{[18,19,37,39,54,56]}$. They are capable of transforming into a limited number of cellular phenotypes within a given family and there is some thought that they may induce further local transformation of cells in a microenvironment through paracrine influences. In 2001, Zuk et al. ${ }^{[13]}$ reported a source of mesenchymal stem cells in abundance in one particular tissue - that being fat. During processing with collagenase, they found an abundance of cells known as the stromal vascular fraction (SVF) that includes red and white blood cells, immune cells, endothelial cells, and stem cell precursors ${ }^{[56-80]}$. Their process of isolation and determination of unique physical identifiers known as clusters of differentiation allowed the identification of a variety of cells that with multipotent potential. Various processing techniques have been utilized to isolate these cells. Collagen isolation is perhaps the most efficient but concerns with the FDA on the use of collagen in the clinical environment and regulations on minimal manipulation have led to the search for alternative options such as other processing techniques, filtering or drying, washing, or centrifugation.

While SVF may contribute to regeneration by its different components, it may also use a paracrine signaling as a means for regeneration based on cross-talk between different cell populations ${ }^{[11,12]}$. Coculture of SVF with adipocytes has yielded induced progenitor preadipocyte formations. SVF can also promote angiogenesis and neovascularization. We believe that this has great opportunities in the clinical setting for promoting wound healing, particularly in patients with diabetes and other chronic diseases. Co-implantation of SVF with endothelial progenitor cells and adipose derived stem cells (ADSCs) resulted in improved neovascularization potential ${ }^{[11]}$. With lipotransfer there is often significant volume loss but combining with SVF has demonstrated enrichment of fat revascularization, probably through this mechanism of promoting secretion of a diverse array of cytokines. SVF can also be used to create highly vascularized tissue engineered human dermo-epidermal skin substitutes for burn wounds. Rigotti postulated a common sequence of events occurring when SVF is transplanted to radiation-damaged tissue that ultimately results in tissue reperfusion and recovery of some of the damaged $\operatorname{skin}^{[50,81-92]}$.

Many of therapeutic studies have also described an initial decrease in inflammation and immune response at the site of SVF injection. When applied to certain disease models, it also tends to decrease inflammatory cytokines and growth factors ${ }^{[92-117]}$.

SVF also has a regenerative capacity, probably through the release of cytokines. SVF increases proliferation of fibroblasts when injected in diabetic foot ulcers. There is also some evidence that it might promote nerve regeneration ${ }^{[21]}$. Diabetic foot disease is a multibillion dollar drain to the health care system, thus utilization of options that could prevent or improve wound healing would be monumental.

Once isolated from adipose tissue, the stromal cell populations represent a diverse collection of cell types. The key concept however is that they are free of lipid and one can mark the cell types with numerous CD (cluster of differentiation) markers. Endothelial precursors are distinctive for bearing the CD 31 antigen and comprise approximately $25 \%-30 \%$ of the mixture of cells. It should be noted however that endothelial precursors bear more markers than just CD 31. Cells for CD 34 markers are considered early multipotent progenitor cells and are considered the true "pre-adipocyte". Further "pericytes" are thought to give rise to many of the stromal cell populations. Stem cells sense and respond through differentiation to various mechanical cues, growth factors adhesive ligand density, and other factors. It is not only cell differentiation but also cell proliferation, angiogenesis, and cell signaling that are affected by these factors. The rest of this manuscript considers the use of these cells in the clinical setting ${ }^{[11,12]}$. 
Type II Collagen

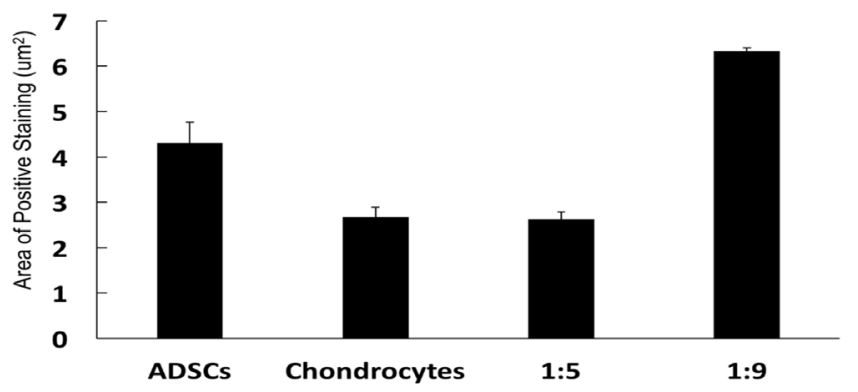

Figure 1. The paraffin embedded sections were also stained for type II collagen. The images were quantified, and the 1:9 condition showed the highest level of staining, which was significantly greater than the chondrocytes alone. ADSCs: adipose derived stem cells

It should be noted that, although clinically there does not appear to be an increased influence on carcinogenesis, several studies indicate that ADSC/ADSC secretomes significantly stimulate proliferation transmigration and 3D invasion of primary normal and tumor epithelial cells ${ }^{[118-120]}$.

Soft Tissue Augmentation and Regeneration is often completed by fat grafting. Variable percentages of absorption occur with fat grafting and volume estimation and preservation may not be optimal ${ }^{[25]}$. The SVF can provide various growth factors such as vascular endothelial growth factor that can promote neovascularization as well as other growth factors through a technique coined as cell-assisted lipotransfer ${ }^{[62,63]}$. Utilization of ways to preserve and maintain fat moving forward under the FDA guidelines will help us utilize these options for future clinical studies.

Other studies in our laboratory involve the utilization of ADSCs as a source for chondrocyte progenitors. Porcine chondrocytes can be successfully isolated, expanded, frozen, and thawed, but past a certain point they lose their chondrogenic features. Co-culturing these chondrocytes with ADSCs on AAM (allograft adipose matrix) was hypothesized to enhance their chondrogenic features. Chondrocytes were cocultured on disc with varying concentrations. After 10 weeks in culture, the discs were paraffin imbedded and stained with H\&E. The 1:5 and 1:9 conditions (chondrocytes:ADSCs) demonstrated evidence of extracellular matrix deposition with the 1:9 condition showing a more compact tissue structure, indicating potential chondrogenesis. The paraffin imbedded sections were also stained for type II collagen [Figure 1] with the 1:9 condition showing the highest level of staining, which was significantly greater than the chondrocytes alone. Because the chondrocytes were from porcine and the ADSCs were from human, the contribution of each cell type to chondrogenesis was able to be determined. Hy-PYD (Hydroxylysyl Pyridinoline) assesses collagen crosslinking [Figure 2]. Here, the expression of Hy-PYD was assessed from the discs by enzyme-linked immunosorbent assay (ELISA) and the 1:9 condition increased the expression over the chondrocytes alone. The 1:9 condition was significantly greater than the 1:5 condition. This indicated that ADSCs were stimulating the chondrocytes to be more chondrogenic. The supernatants were collected from the co-culture wells for each condition. ELISA tests were conducted to assess the secretion of type II collagen using species specific antibodies. The human collagen II results were normalized to the chondrocytes because they were presumed to show no expression, and the porcine collagen II results were normalized to the ADSCs, which were presumed to show no expression. The ELISAs were conducted using the supernatants from the collections at Weeks 3, 5, 7, and 9 [Figure 3]. For the human collagen II expression, there was essentially no expression throughout the experiment. However, for the porcine expression, there was a time-dependent increase for the 1:9 co-culture condition, with the nine-week reading showing the highest expression of any of the supernatants tested. The other conditions did not reveal any distinct pattern, indicating that the 1:5 co-culture condition was not different from culturing the chondrocytes alone. In summary, porcine ADSCs can be successfully isolated, expanded, frozen, and 


\section{Hy-PYD ELISA}

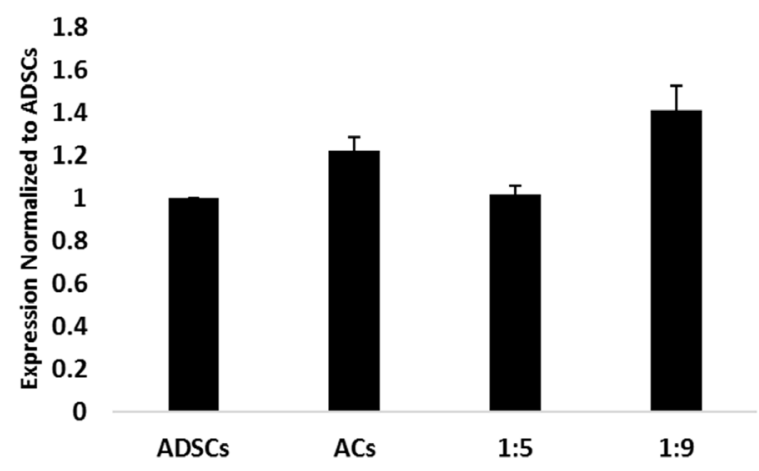

Figure 2. Because the chondrocytes were from porcine and the ADSCs were from human, we determined the contribution of each cell type to chondrogenesis. Hy-PYD assesses collagen crosslinking. Here, the expression of Hy-PYD was assessed from the discs by ELISA, and the 1:9 condition increased the expression over the chondrocytes alone. The 1:9 condition was significantly greater than the 1:5 condition. This indicated that ADSCs were stimulating the chondrocytes to be more chondrogenic. ADSCs: adipose derived stem cells; ELISA: enzyme-linked immunosorbent assay

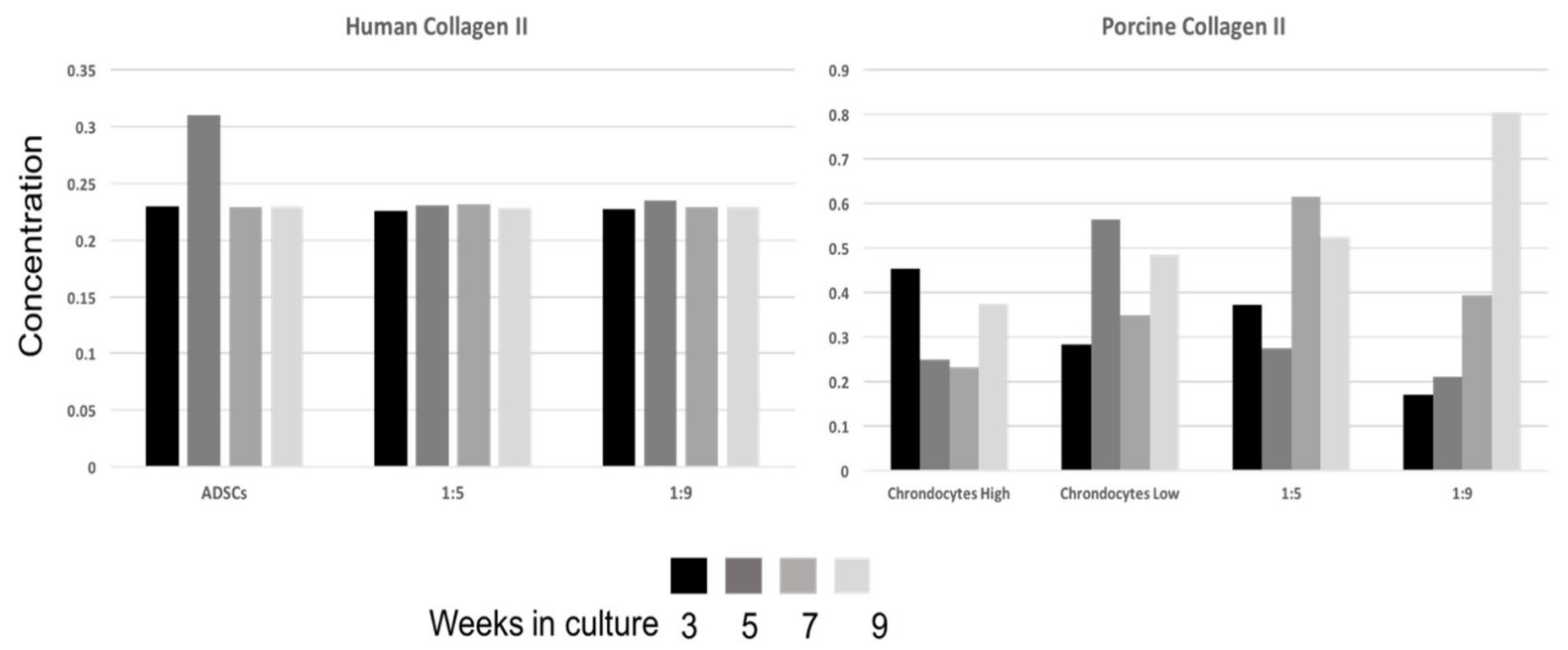

Figure 3. The supernatants were collected from the co-culture wells for each condition. Then, ELISA tests were conducted to assess the secretion of type II collagen using species specific antibodies. The human collagen II results were normalized to the chondrocytes because they were presumed to show no expression, and the porcine collagen II results were normalized to the ADSCs, which were presumed to show no expression. The ELISAs were conducted using the supernatants from the collections at Weeks 3, 5, 7, and 9. For the human collagen II expression, there was essentially no expression throughout the experiment. However, for the porcine expression, there was a time-dependent increase for the 1:9 co-culture condition, with the nine-week reading showing the highest expression of any of the supernatants tested. The other conditions did not reveal any distinct pattern, indicating that the 1:5 co-culture was not different from culturing the chondrocytes alone. All quantitative data are expressed as the mean \pm SD. A Student's $t$-test was performed to assess the differences between the groups. A $P$-value $<0.05$ was considered statistically significant. ADSCs: adipose derived stem cells; ELISA: enzyme-linked immunosorbent assay

thawed, but past a certain point they lose their chondrogenic features. Co-culturing these chondrocytes with ADSCs on AAM enhanced their chondrogenic features, revealing more structural changes, an increase in Hy-PYD and type II collagen staining, and secretion in the 1:9 (Chondrocytes:ADSCs) coculture condition. Chondrocytes contribute to the production of collagen, and the presence of the ADSCs increases this production when these cells were cultured on $\mathrm{AAM}^{[118-125]}$.

Recent studies have utilized newer techniques for soft tissue augmentation. Rigotti evaluated a noninvasive technique, which he calls biological morphogenetic surgery, that can enlarge or reduce the shape and 
volume of soft tissues by utilizing cannulas and augmentation with fat cells. He also noted an increase in adipose tissue under tissue expanders placed in rats below the latissimus muscle. The thought is that the tensile pressure associated with the tissue expander leads to adipose deposits ${ }^{[121,122]}$.

Wound healing issues are a multibillion dollars business and the use of ADSCs offer potential therapeutic options. ADSCs have been promoted as favorable candidates for wound therapies and they secrete numerous growth factors and cytokines critical in repair. Recent studies have indicated that ADSCs may reverse or improve radiation-induced lesions as well as atrophy and scarring ${ }^{[94]}$. Animal studies suggest that the release of keratinocyte growth factor and the differentiation of ADSCs toward endothelial and epithelial cell line phenotypes may be the mechanisms of action. Further, the angiogenic properties of ADSCs may also benefit complications secondary to ischemia. Autogenous transplantation has demonstrated some promise in improving ankle-brachial index and transcutaneous oxygen pressure. ADSCs may also be useful for the treatment of pathological wound healing in the context of hypertrophic scar formation ${ }^{[20]}$.

In addition, SVF and ADSCs have been used to promote extracellular matrix (ECM) synthesis, the groundwork for wound healing. The extracellular matrix acts as a potent scaffold in many tissue types, accelerating the regenerative functions of nearby cells. It is comprised of structural proteins such as collagen, laminin, fibronectin, and elastin, which are commonly secreted by the fibroblast ${ }^{[12]}$. Furthermore, the ECM contributes to the growth of vascular networks by mediating morphogenesis and migration speeds during angiogenesis. Since the SVF contains matrix-secreting fibroblasts and other stromal cells, the application of SVF is potentially advantageous for laying down the foundations for wound healing ${ }^{[11]}$.

Finally, skin rejuvenation may have promise with ADSC use. It may be possible that these cells could reverse atrophic and photo-damaged cells. Animals studies have demonstrated that subcutaneous ADSC injections increase dermal thickness and collagen density in aged mice and perhaps reduced wrinkles induced by UVB-irradiation ${ }^{[11,12]}$.

Our laboratory has also studied the mechanism of fat formation using acellularized adipose matrix by deconstructing adipo-induction in this acellularized adipose matrix (AAM). It has been observed that AAM injected subcutaneously in an area relatively devoid of fat may initiate lipogenesis. Because of this observation, our global aim was to delineate the sequence of events occurring following implantation of AAM to the final process of adipogenesis. We wanted to compare adipoinduction of adipose/fascia complex to that of adipose fraction alone - analyzing proteomics, bioinformatics, early and late cellular infiltrates, cytokines, adipokines, and enzymes (related to macrophage phenotype and lipoproteins). In addition, we examined the genesis of the adipocytes required to achieve a lipofilling effect, and detailed the involvement of stromal and stem cells in recruiting host tissue to fill the void via adipogenesis, neovascularization and fibrosis ${ }^{[120]}$.

Recently, several groups have started to examine the use of human AAM as a scaffold for tissue engineering, which shows great promise as a vehicle for adipose stem cell delivery as well as a construct that promotes soft tissue regeneration though acellular mechanisms ${ }^{[119]}$. AAM secretes growth factors with adipo- and angio-inductive characteristics [vascular endothelial growth factor, bFGF (fibroblast growth factors), platelet-derived growth factor, and TGF- $\beta$ (transforming growth factor)] and recruits preadipocytes, pericytes, and other cells responsible for local tissue regeneration. Degradation products of the ECM trigger a change in macrophage phenotype that can bring about progenitor cell recruitment ${ }^{[120]}$.

Micronanobubbles (MNBs) technology is another area of exploration in fat graft survival. The bubbles afford the opportunity oxygenate tissues without the expense of utilizing hyperbaric chambers or other nonmobile options. What are the properties that make MNBs unique? MNBs are very small bubbles 
in solution that slowly release their oxygen gas into the solution in which they are formed, providing a revolutionary new modality for tissue oxygenation. Strong data have demonstrated improved wound oxygenation, transplant survival and preservation times. This may have major implications for plastic surgery: oxygenation of lipoaspirate and improved fat graft survival ${ }^{[117]}$.

\section{CONCLUSION}

Fat and stem cell technology offer tremendous clinical applications in plastic surgery. We still need to continue to work on the science of this technology. Only by understanding the molecular and tissue interactions will we be able to modify and utilize this technology to its full advantage.

\section{DECLARATIONS}

\section{Authors' contributions}

Dr Evans and Widgerow contribution was equal

\section{Availability of data and materials}

Not applicable.

\section{Financial support and sponsorship}

None.

\section{Conflicts of interest}

Both authors declared that there are no conflicts of interest.

\section{Ethical approval and consent to participate}

Not applicable.

\section{Consent for publication}

Not applicable.

\section{Copyright}

(c) The Author(s) 2020.

\section{REFERENCES}

1. Takahashi K, Yamanaka S. Induction of pluripotent stem cells from mouse embryonic and adult fibroglast cultures by defined factors. Cell 2006;126:633-76.

2. Lowry WE, Richter L, Yachechko R, Pyle AD, Tchieu J, et al. Generation of human induced pluripotent stem cells from dermal fibroblasts. Proc Natl Acad Sci U S A 2008;105:2883-8.

3. Hanna J, Markoulaki S, Schorderet P, Carey BW, Beard C, et al. Direct reprogramming of terminally differentiated mature B lymphocytes to pluripotency. Cell 2008;133:250-64.

4. Aasen T, Raya A, Barrero MJ, Garreta E, Consiglio A, et al. Efficient and rapid generation of induced pluripotent stem cells from human keratinoctyes. Nat Biotechnol 2008;26:1276-84.

5. Takenaka C, Nishishita N, Takada N, Jakt LM, Kawamata S. Effective generation of iPS cells from CD 34+ cord blodd cells by inhibition of p53. Exp Hematol 2010; 38:154-62.

6. Phanthong P, Raveh-Amit H, Li T, Kitiyanant Y, Dinnyes A. Is aging a barrier to reprogramming? Lessons from induced pluripotent stem cells. Biogerontology 2013;14:591-602.

7. Gonzalez F, Barragan Monasterio M, Tiscornia G, Montserrat Pulido N, et al. Generation of mouse-induced pluripotent stem cells by transient expression of a single nonviral polycistronic vector. Proc Natl Acad Sci USA 2009;106:8918-22.

8. Okita K, Nakagawa M, Hyenjong H, Ichisaka T, Yamanaka S. Generation of mouse induced pluripotent stem cells without viral vectors. Science 2008;322:949-53.

9. Steinemann D, Gohring G, Schlegelberger B. Genetic instability of modified stem cells - a first step towards malignant transformation. Am J Stem Cells 2013;2:39-51.

10. Mayshar Y, Ben-David U, Lavon N, Biancotti JC, Yakir B, et al. Identification and classification of chromosomal aberrations in human 
induced pluripotent stem cells. Cell Stem Cell 2010;7:521-31.

11. Guo J, Nguyen A, Banyard DA, Fadavi D, Toranto JD, et al. Stromal vascular fraction: a regenerative reality? Part 2: mchanisms of regenerative action. J Plast Reconstr Aesthet Surg 2016;69:180-8.

12. Nguyen A, Guo J, Fadavi D, Banyard D, Toranto J, et al. Stromal vascular fraction - a regenerative reality? Part 1 - current concepts and review of the literature. J Plast Reconstr Aesthet Surg 2016;69:170-9.

13. Zuk PA, Zhu M, Mizuno H, Huang J, Futrell JW, et al. Multilineage cells from human adipose tissue: implications for cell-based therapies. Tissue Eng 2001;7:211-28.

14. Riordan NH, Ichim TE, Min WP, Wang H, Solano F, et al. Non-expanded adipose stromal vascular fraction cell therapy for multiple sclerosis. J Transl Med 2009;7:29.

15. Yoshimura K, Sato K, Aoi N, Kurita M, Hirohi T, et al. Cell-assisted lipotransfer for cosmetic breast augmentation: supportive use of adipose-derived stem/stromal cells. Aesthetic Plast Surg 2008;32:48-55.

16. van Dijk A, Naaijkens BA, Jurgens WJ, Nalliah K, Sairras S, et al. Reduction of infarct size by intravenous injection of uncultured adipose derived stromal cells in a rat model is dependent on the time point of application. Stem Cell Res 2011;7:219-29.

17. Atalay S, Coruh A, Deniz K. Stromal vascular fraction improves deep partial thickness burn wound healing. Burns 2014;40:1375-83.

18. Rajashekhar G, Ramadan A, Abburi C, Callaghan B, Traktuev DO, et al. Regenerative therapeutic potential of adipose stromal cells in early stage diabetic retinopathy. PLoS One 2014;9:e84671.

19. Chung MT, Zimmermann AS, Paik KJ, Morrison SD, Hyun JS, et al. Isolation of human adipose-derived stromal cells using laser-assisted liposuction and their therapeutic potential in regenerative medicine. Stem Cells Trans1 Med 2013;2:808-17.

20. You HJ, Han SK. Cell therapy for wound healing. J Korean Med Sci 2014;29:311-9.

21. Jarajapu YP, Grant MB. The promise of cell-based therapies for diabetic complications: challenges and solutions. Circ Res 2010;106:85469.

22. Tocco I, Widgerow AD, Lalezari S, Banyard D, Shaterian A, et al. Lipotransfer: the potential from bench to bedside. Ann Plast Surg 2014;72:599-609.

23. Kakagia D, Pallua N. Autologous fat grafting: in search of the optimal technique. Surg Innov 2014;21:327-36.

24. Eto H, Ishimine H, Kinoshita K, Watanabe-Susaki K, Kato H, et al. Characterization of human adipose tissue-resident hematopoietic cell populations reveals a novel macrophage subpopulation with CD34 expression and mesenchymal multipotency. Stem Cells Dev 2013;22:985-97.

25. Karacaoglu E, Kizilkaya E, Cermik H, Zienowicz R. The role of recipient sites in fat-graft survival: experimental study. Ann Plast Surg 2005;55:63-8.

26. Matsumoto D, Sato K, Gonda K, Takaki Y, Shigeura T, et al. Cell-assisted lipotransfer: supportive use of human adipose-derived cells for soft tissue augmentation with lipoinjection. Tissue Eng 2006;12:3375-82.

27. Tanikawa DY, Aguena M, Bueno DF, Passos-Bueno MR, Alonso N. Fat grafts supplemented with adipose-derived stromal cells in the rehabilitation of patients with craniofacial microsomia. Plast Reconstr Surg 2013;132:141-52.

28. Peltoniemi HH, Salmi A, Miettinen S, Mannerström B, Saariniemi K, et al. Stem cell enrichment does not warrant a higher graft survival in lipofilling of the breast: a prospective comparative study. J Plast Reconstr Aesthet Surg 2013;66:1494-503.

29. Kakudo N, Tanaka Y, Morimoto N, Ogawa T, Kushida S, et al. Adipose-derived regenerative cell (ADRC)-enriched fat grafting: optimal cell concentration and effects on grafted fat characteristics. J Transl Med 2013;11:254.

30. Kamakura T, Ito K. Autologous cell-enriched fat grafting for breast augmentation. Aesthetic Plast Surg 2011;35:1022-30.

31. Chatterjee S, Laliberte M, Blelloch S, Ratanshi I, Safneck J, et al. Adipose-derived stromal vascular fraction differentially expands breast progenitors in tissue adjacent to tumors compared to healthy breast tissue. Plast Reconstr Surg 2015;136:414e-25.

32. Mandel K, Yang Y, Schambach A, Glage S, Otte A, et al. Mesenchymal stem cells directly interact with breast cancer cells and promote tumor cell growth in vitro and in vivo. Stem Cells Dev 2013;22:3114-27.

33. Rowan BG, Gimble JM, Sheng M, Anbalagan M, Jones RK, et al. Human adipose tissue-derived stromal/stem cells promote migration and early metastasis of triple negative breast cancer xenografts. PLoS One 2014;9:e89595.

34. Zimmerlin L, Donnenberg AD, Rubin JP, Basse P, Landreneau RJ, et al. Regenerative therapy and cancer: in vitro and in vivo studies of the interaction between adipose-derived stem cells and breast cancer cells from clinical isolates. Tissue Eng Part A 2011;17:93-106.

35. Charles-de-Sá L, Gontijo-de-Amorim NF, Maeda Takiya C, Borojevic R, Benati D, et al. Antiaging treatment of the facial skin by fat graft and adipose-derived stem cells. Plast Reconstr Surg 2015;135:999-1009.

36. Bourin P, Bunnell BA, Casteilla L, Dominici M, Katz AJ, et al. Stromal cells from the adipose tissue-derived stromal vascular fraction and culture expanded adipose tissue-derived stromal/stem cells: a joint statement of the International Federation for Adipose Therapeutics and Science (IFATS) and the International Society for Cellular Therapy (ISCT). Cytotherapy 2013;15:641-8.

37. Banyard DA, Salibian AA, Widgerow AD, Evans GR. Implications for human adipose-derived stem cells in plastic surgery. J Cell Mol Med 2015;19:21-30.

38. Gir P, Oni G, Brown SA, Mojallal A, Rohrich RJ. Human adipose stem cells: current clinical applications. Plast Reconstr Surg 2012;129:1277-90.

39. Liras A. Future research and therapeutic applications of human stem cells: general, regulatory, and bioethical aspects. J Transl Med 2010;8:131.

40. Tonnard P, Verpaele A, Peeters G, Hamdi M, Cornelissen M, et al. Nanofat grafting: basic research and clinical applications. Plast Reconstr Surg 2013;132:1017-26.

41. Stuzin JM. Discussion: nanofat grafting: basic research and clinical applications. Plast Reconstr Surg 2013;132:1027-8. 
42. Pereira Lopes FR, Camargo de Moura Campos L, Dias Corrêa J Jr, Balduino A, Lora S, et al. Bone marrow stromal cells and resorbable collagen guidance tubes enhance sciatic nerve regeneration in mice. Exp Neurol 2006;198:457-68.

43. Mohammadi R, Sanaei N, Ahsan S, Rostami H, Abbasipour-Dalivand S, et al. Repair of nerve defect with chitosan graft supplemented by uncultured characterized stromal vascular fraction in streptozotocin induced diabetic rats. Int J Surg 2014;12:33-40.

44. Papalia I, Raimondo S, Ronchi G, Magaudda L, Giacobini-Robecchi MG, et al. Repairing nerve gaps by vein conduits filled with lipoaspirate-derived entire adipose tissue hinders nerve regeneration. Ann Anat 2013;195:225-30.

45. Constantinescu CS, Farooqi N, O'Brien K, Gran B. Experimental autoimmune encephalomyelitis (EAE) as a model for multiple sclerosis (MS). Br J Pharmacol 2011;164:1079-106.

46. Ricco JB, Thanh Phong L, Schneider F, Illuminati G, Belmonte R, et al. The diabetic foot: a review. J Cardiovasc Surg (Torino) 2013;54:755-62.

47. Han SK, Kim HR, Kim WK. The treatment of diabetic foot ulcers with uncultured, processed lipoaspirate cells: a pilot study. Wound Repair Regen 2010;18:342-8.

48. Lv SS, Liu G, Wang JP, Wang WW, Cheng J, et al. Mesenchymal stem cells transplantation ameliorates glomerular injury in streptozotocin-induced diabetic nephropathy in rats via inhibiting macrophage infiltration. Int Immunopharmacol 2013;17:275-82.

49. Perbeck L, Celebioglu F, Svensson L, Danielsson R. Lymph circulation in the breast after radiotherapy and breast conservation. Lymphology 2006;39:33-40.

50. Rigotti G, Marchi A, Galiè M, Baroni G, Benati D, et al. Clinical treatment of radiotherapy tissue damage by lipoaspirate transplant: a healing process mediated by adipose-derived adult stem cells. Plast Reconstr Surg 2007;119:1409-22.

51. Gimble JM, Bunnell BA, Chiu ES, Guilak F. Concise review: Adipose-derived stromal vascular fraction cells and stem cells: let's not get lost in translation. Stem Cells 2011;29:749-54.

52. Laass MW, Roggenbuck D, Conrad K. Diagnosis and classification of Crohn's disease. Autoimmun Rev 2014;13:467-71.

53. Sartor RB. Mechanisms of disease: pathogenesis of Crohn's disease and ulcerative colitis. Nat Clin Pract Gastroenterol Hepatol 2006;3:390-407.

54. Dalal J, Gandy K, Domen J. Role of mesenchymal stem cell therapy in Crohn's disease. Pediatr Res 2012;71:445-51.

55. Thesleff T, Lehtimäki K, Niskakangas T, Mannerström B, Miettinen S, et al. Cranioplasty with adipose-derived stem cells and biomaterial: a novel method for cranial reconstruction. Neurosurgery 2011;68:1535-40.

56. Sándor GK, Tuovinen VJ, Wolff J, Patrikoski M, Jokinen J, et al. Adipose stem cell tissue-engineered construct used to treat large anterior mandibular defect: a case report and review of the clinical application of good manufacturing practice-level adipose stem cells for bone regeneration. J Oral Maxillofac Surg 2013;71:938-50.

57. Wilson SM, Goldwasser MS, Clark SG, Monaco E, Bionaz M, et al. Adipose-derived mesenchymal stem cells enhance healing of mandibular defects in the ramus of swine. J Oral Maxillofac Surg 2012;70:e193-203.

58. Mehrkens A, Saxer F, Güven S, Hoffmann W, Müller AM, et al. Intraoperative engineering of osteogenic grafts combining freshly harvested, human adipose-derived cells and physiological doses of bone morphogenetic protein-2. Eur Cell Mater 2012;24:308-19.

59. Araña M, Gavira JJ, Peña E, González A, Abizanda G, et al. Epicardial delivery of collagen patches with adipose-derived stem cells in rat and minipig models of chronic myocardial infarction. Biomaterials 2014;35:143-51.

60. Khalpey Z, Janardhanan R, Konhilas J, Hemphill C. et al. First in man: adipose-derived stromal vascular fraction cells may promote restorative cardiac function. Am J Med 2014;127:e11-2.

61. Gimble JM, Katz AJ, Bunnell BA. Adipose-derived stem cells for regenerative medicine. Circ Res 2007;100:1249-60.

62. Yoshimura K, Shigeura T, Matsumoto D, Sato T, Takaki Y, et al. Characterization of freshly isolated and cultured cells derived from the fatty and fluid portions of liposuction aspirates. J Cell Physiol 2006;208:64-76.

63. Yoshimura K. Cell-assisted lipotransfer for breast augmentation: grafting of progenitor-enriched fat tissue. In: Shiffman MA, editors. Autologous fat transfer. Springer, Berlin, Heidelberg; 2010. pp. 261-71.

64. ClinicalTrials.gov. ClinicalTrials.gov Search of Stromal Vascular Fraction. Available from: https://clinicaltrials.gov/ct2/results?term=stro mal+vascular+fraction\&pg=2 [Last accessed on 11 Mar 2020]

65. Gentile P, Orlandi A, Scioli MG, Di Pasquali C, Bocchini I, et al. Concise review: adipose-derived stromal vascular fraction cells and platelet-rich plasma: basic and clinical implications for tissue engineering therapies in regenerative surgery. Stem Cells Transl Med 2012;1:230-6.

66. Jurgens WJ, Kroeze RJ, Zandieh-Doulabi B, van Dijk A, Renders GA, et al. One-step surgical procedure for the treatment of osteochondral defects with adipose-derived stem cells in a caprine knee defect: a pilot study. Biores Open Access 2013;2:315-25.

67. Semon JA, Zhang X, Pandey AC, Alandete SM, Maness C, et al. Administration of murine stromal vascular fraction ameliorates chronic experimental autoimmune encephalomyelitis. Stem Cells Transl Med 2013;2:789-96.

68. Astori G, Vignati F, Bardelli S, Tubio M, Gola M, et al. "In vitro" and multicolor phenotypic characterization of cell subpopulations identified in fresh human adipose tissue stromal vascular fraction and in the derived mesenchymal stem cells. J Transl Med 2007;5:55.

69. Watson JE, Patel NA, Carter G, Moor A, Patel R, et al. Comparison of markers and functional attributes of human adipose-derived stem cells and dedifferentiated adipocyte cells from subcutaneous fat of an obese diabetic donor. Adv Wound Care (New Rochelle) 2014;3:21928.

70. Sumi M, Sata M, Toya N, Yanaga K, Ohki T, et al. Transplantation of adipose stromal cells, but not mature adipocytes, augments ischemia-induced angiogenesis. Life Sci 2007;80:559-65.

71. Zeyda M, Farmer D, Todoric J, Aszmann O, Speiser M, et al. Human adipose tissue macrophages are of an anti-inflammatory phenotype but capable of excessive pro-inflammatory mediator production. Int J Obes (Lond) 2007;31:1420-8. 
72. Tiemessen MM, Jagger AL, Evans HG, van Herwijnen MJ, John S, et al. CD4+CD25+Foxp3+ regulatory T cells induce alternative activation of human monocytes/macrophages. Proc Natl Acad Sci U S A 2007;104:19446-51.

73. Choi JS, Kim BS, Kim JY, Kim JD, Choi YC, et al. Decellularized extracellular matrix derived from human adipose tissue as a potential scaffold for allograft tissue engineering. J Biomed Mater Res A 2011;9:292-9.

74. Eckes B, Nischt R, Krieg T. Cell-matrix interactions in dermal repair and scarring. Fibrogenesis Tissue Repair 2010;3:4.

75. Traktuev DO, Prater DN, Merfeld-Clauss S, Sanjeevaiah AR, Saadatzadeh MR, et al. Robust functional vascular network formation in vivo by cooperation of adipose progenitor and endothelial cells. Circ Res 2009;104:1410-20.

76. Dominici M, Le Blanc K, Mueller I, Slaper-Cortenbach I, Marini F, et al. Minimal criteria for defining multipotent mesenchymal stromal cells. The International Society for Cellular Therapy position statement. Cytotherapy 2006;8:315-7.

77. Sidney LE, Branch MJ, Dunphy SE, Dua HS, Hopkinson A. Concise review: evidence for cd34 as a common marker for diverse progenitors. Stem Cells 2014;32:1380-9.

78. Corselli M, Crisan M, Murray IR, West CC, Scholes J, et al. Identification of perivascular mesenchymal stromal/stem cells by flow cytometry. Cytometry A 2013;83:714-20.

79. Hager G, Holnthoner W, Wolbank S, Husa AM, Godthardt K, et al. Three specific antigens to isolate endothelial progenitor cells from human liposuction material. Cytotherapy 2013;15:1426-35.

80. Navarro A, Marín S, Riol N, Carbonell-Uberos F, Miñana MD. Human adipose tissue-resident monocytes exhibit an endothelial-like phenotype and display angiogenic properties. Stem Cell Res Ther 2014;5:50.

81. Blaber SP, Webster RA, Hill CJ, Breen EJ, Kuah D, et al. Analysis of in vitro secretion profiles from adipose-derived cell populations. J Transl Med 2012;10:172.

82. Chazenbalk G, Bertolotto C, Heneidi S, Jumabay M, Trivax B, et al. Novel pathway of adipogenesis through cross-talk between adipose tissue macrophages, adipose stem cells and adipocytes: evidence of cell plasticity. PLoS One 2011;6:e17834.

83. Cianfarani F, Toietta G, Di Rocco G, Cesareo E, Zambruno G, et al. Diabetes impairs adipose tissue-derived stem cell function and efficiency in promoting wound healing. Wound Repair Regen 2013;21:545-53.

84. Li J, Gao J, Cha P, Chang Q, Liao Y, et al. Supplementing fat grafts with adipose stromal cells for cosmetic facial contouring. Dermatol Surg 2013;39:449-56.

85. Chung MT, Paik KJ, Atashroo DA, Hyun JS, McArdle A, et al. Studies in fat grafting: Part I. Effects of injection technique on in vitro fat viability and in vivo volume retention. Plast Reconstr Surg 2014;134:29-38.

86. Premaratne GU, Ma LP, Fujita M, Lin X, Bollano E, et al. Stromal vascular fraction transplantation as an alternative therapy for ischemic heart failure: anti-inflammatory role. J Cardiothorac Surg 2011;6:43.

87. Koh YJ, Koh BI, Kim H, Joo HJ, Jin HK, et al. Stromal vascular fraction from adipose tissue forms profound vascular network through the dynamic reassembly of blood endothelial cells. Arterioscler Thromb Vasc Biol 2011;31:1141-50.

88. Rehman J, Traktuev D, Li J, Merfeld-Clauss S, Temm-Grove CJ, et al. Secretion of angiogenic and antiapoptotic factors by human adipose stromal cells. Circulation 2004;109:1292-8.

89. Kølle SF, Fischer-Nielsen A, Mathiasen AB, Elberg JJ, Oliveri RS, et al. Enrichment of autologous fat grafts with ex-vivo expanded adipose tissue-derived stem cells for graft survival: a randomised placebo-controlled trial. Lancet 2013;382:1113-20.

90. Armulik A, Abramsson A, Betsholtz C. Endothelial/pericyte interactions. Circ Res 2005;97:512-23.

91. Kwon HM, Hur SM, Park KY, Kim CK, Kim YM, et al. Multiple paracrine factors secreted by mesenchymal stem cells contribute to angiogenesis. Vascul Pharmacol 2014;63:19-28.

92. Zhu M, Dong Z, Gao J, Liao Y, Xue J, et al. Adipocyte regeneration after free fat transplantation: promotion by stromal vascular fraction cells. Cell Transplant 2015;24:49-62.

93. Fu S, Luan J, Xin M, Wang Q, Xiao R, et al. Fate of adipose-derived stromal vascular fraction cells after co-implantation with fat grafts: evidence of cell survival and differentiation in ischemic adipose tissue. Plast Reconstr Surg 2013;132:363-73.

94. Paik KJ, Zielins ER, Atashroo DA, Maan ZN, Duscher D, et al. Studies in fat grafting: part v. cell-assisted lipotransfer to enhance fat graft retention is dose dependent. Plast Reconstr Surg 2015;136:67-75.

95. Klar AS, Güven S, Biedermann T, Luginbühl J, Böttcher-Haberzeth S, et al. Tissue-engineered dermo-epidermal skin grafts prevascularized with adipose-derived cells. Biomaterials 2014;35:5065-78.

96. Barba M, Cicione C, Bernardini C, Michetti F, Lattanzi W. Adipose-derived mesenchymal cells for bone regereneration: state of the art. Biomed Res Int 2013;2013:416391.

97. di Summa PG, Kingham PJ, Raffoul W, Wiberg M, Terenghi G, et al. Adipose-derived stem cells enhance peripheral nerve regeneration. J Plast Reconstr Aesthet Surg 2010;63:1544-52.

98. Pereira Lopes FR, Lisboa BC, Frattini F, Almeida FM, Tomaz MA, et al. Enhancement of sciatic nerve regeneration after vascular endothelial growth factor (VEGF) gene therapy. Neuropathol Appl Neurobiol 2011;37:600-12.

99. Badylak SF. The extracellular matrix as a scaffold for tissue reconstruction. Semin Cell Dev Biol 2002;13:377-83.

100. Bosman FT, Stamenkovic I. Functional structure and composition of the extracellular matrix. J Pathol 2003;200:423-8.

101. Alberts B. Molecular biology of the cell. 4th ed. New York: Garland Science; 2002. pp. 1548.

102. Sheetz MP, Felsenfeld DP, Galbraith CG. Cell migration: regulation of force on extracellular-matrix-integrin complexes. Trends Cell Biol $1998 ; 8: 51-4$.

103. Friedl P, Zanker KS, Brocker EB. Cell migration strategies in 3-D extracellular matrix: differences in morphology, cell matrix interactions, and integrin function. Microsc Res Tech 1998;43:369-78.

104. Bauer AL, Jackson TL, Jiang Y. Topography of extracellular matrix mediates vascular morphogenesis and migration speeds in 
angiogenesis. PLoS Comput Biol 2009;5:e1000445.

105. Choi JS, Yang HJ, Kim BS, Kim JD, Kim JY, et al. Human extracellular matrix (ECM) powders for injectable cell delivery and adipose tissue engineering. J Control Release 2009;139:2-7.

106. Debels H, Gerrand YW, Poon CJ, Abberton KM, Morrison WA, et al. An adipogenic gel for surgical reconstruction of the subcutaneous fat layer in a rat model. J Tissue Eng Regen Med 2017;11:1230-41.

107. Choi JH, Bellas E, Vunjak-Novakovic G, Kaplan DL. Adipogenic differentiation of human adipose-derived stem cells on 3D silk scaffolds. Methods Mol Biol 2011;702:319-30.

108. Chernousov MA, Yu WM, Chen ZL, Carey DJ, Strickland S. Regulation of Schwann cell function by the extracellular matrix. Glia 2008;56:1498-507.

109. Brown BN, Londono R, Tottey S, Zhang L, Kukla KA, et al. Macrophage phenotype as a predictor of constructive remodeling following the implantation of biologically derived surgical mesh materials. Acta Biomater 2012;8:978-87.

110. Mills SJ, Cowin AJ, Kaur P. Pericytes, mesenchymal stem cells and the wound healing process. Cells 2013;2:621-34.

111. Caplan AI, Correa D. The MSC: an injury drugstore. Cell Stem Cell 2011;9:11-5.

112. Narayanan AS, Page RC, Swanson J. Collagen synthesis by human fibroblasts. Regulation by transforming growth factor-beta in the presence of other inflammatory mediators. Biochem J $1989 ; 260: 463-9$.

113. Newman AC, Nakatsu MN, Chou W, Gershon PD, Hughes CC. The requirement for fibroblasts in angiogenesis: fibroblast-derived matrix proteins are essential for endothelial cell lumen formation. Mol Biol Cell 2011;22:3791-800.

114. Newman AC, Chou W, Welch-Reardon KM, Fong AH, Popson SA, et al. Analysis of stromal cell secretomes reveals a critical role for stromal cell-derived hepatocyte growth factor and fibronectin in angiogenesis. Arterioscler Thromb Vasc Biol 2013;33:513-22.

115. Bianchi F, Maioli M, Leonardi E, Olivi E, Pasquinelli G, et al. A new nonenzymatic method and device to obtain a fat tissue derivative highly enriched in pericyte-like elements by mild mechanical forces from human lipoaspirates. Cell Transplant 2013;22:2063-77.

116. Traktuev DO, Merfeld-Clauss S, Li J, Kolonin M, Arap W, et al. A population of multipotent CD34-positive adipose stromal cells share pericyte and mesenchymal surface markers, reside in a periendothelial location, and stabilize endothelial networks. Circ Res 2008;102:7785.

117. Sayadi LR, Banyard DA, Ziegler ME, Obagi Z, Prussak J, et al. Topical oxygen therapy \& micro/nanobubbles: a new modlity for tissue oxygen delivery. Int Wound J 2018;15:363-74.

118. Kengelback-Weigand A, Tasbihi K, Strissel PL, Schmid R, Marques JM, et al. Plasticity of patient-match normal mammary epithelial cell is dependent on autologous adipose-derived stem cells. Sci Rep 2019;9:10722.

119. Schmid R Wolf K, Robering JW, Strauss S, Strissel PL, et al. ADSCs and adipocytes are the main producers in the autotaxinlysophosphatidic acid axis of breast cancer and healthy mammary tissue in vitro. BMC Cancer 2018;18:1273.

120. Tong J, Mou S, Xiong L, Wang Z, Wang R, et al. Adipose-derived mesenchymal stem cells formed acinar-like structure when stimulated with breast epithelial cells in three-dimensional culture. PLoS One 2018:13;e0204077.

121. Rigotti G, Chirumbolo S. Biologial morphogenetic surgery: a minimally invasive procedure to address different biological mechanisms. Aesthetic Surg J 2019:39:745-55.

122. Rigotti G, Chirumbolo S, Cicala F, Parnigotto PP, Nicolato E, et al. Negative pressure from an internal spiral tissue expander generates new subcutaneous adipose tissue in an in vivo animal model. Aesthe Surg J 2020;40:448-459

123. Ziegler ME, Sorensen AM, Banyard DA, Evans GRD, Widgerow AD. Improving in vivo cartilage generation by co-culturing adiposederived stem cells and chrondrocytes on an allograft adipose matrix framework. Plast Reconstr Surg 2019;83:583-8.

124. Ziegler ME, Sorensen AM, Banyard DA, Tylutki T, Chnari E, et al. Deconstructing Allograft Adipose and Fascia Matrix: implications for improving angiogenesis related to procedures for tissue supplementation and volumization stem cells. USA: Lohrasb Ross Sayadi, MD; 2017.

125. Banyard DA, Borad V, Amezcua E, Wirth GA, Evans GR, et al. Preparation, characterization, and clinical implications of human decellularized adipose tissue extracellular matrix (hDAM): a comprehensive review. Aesthet Surg J 2016;36:349-57. 